\section{Indian Higher Education at the Crossroads}

\section{PaWAN Agarwal}

Pawan Agarwal is Secretary of the Department of Science and Technology and Minority Affairs, government of West Bengal (India). He was a Fulbright New Century Scholar. E-mail: Pawan.agarwalo6@gmail.com.

or the past few years, India has seen high rates of econom-

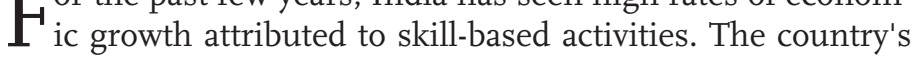
huge pool of qualified manpower fed by its large and growing higher education system is widely seen as contributing to this development. While attracting a significant interest overseas, Indian higher education is in focus at home for other reasons.

Several sectors of the Indian economy face severe skill shortages perceived as caused by the inadequacy of the higher education system. Institutions of higher education produce ordinary graduates with hardly any employable skills. The quality of academic research is low and declining. Overall, academic standards do not compare favorably with the average standards in advanced countries. There are only small peaks of excellence. The reputed Indian Institutes of Technology and the Indian Institutes of Management that represent this peak have been embroiled in many controversies in recent years. A unilateral decision of the government to impose a numerical quota-based reservation for the other backward classes on these institutions created an impasse that raises many prickly issues.

In its November 2006 report to the Indian prime minister, the National Knowledge Commission pointed out the "quiet crises" in Indian higher education. While addressing a gathering of vice chancellors in New Delhi, the national human resource minister recently lamented that Indian higher education is the "sick child" of Indian education. Thus, not surprisingly government is significantly increasing the public funding and setting up many new institutions. The country aspires to raise enrollment levels from a current II percent of the eligible age group to 20 percent by 2012 .

The growth of public funding, new institutions, and increased enrollment all constitute progress. However, the current perceived crisis in Indian higher education involves failed expectations rather than something suddenly going wrong with the system. At a time when the economy is booming, increased expectations are placed upon higher education. The large and growing middle class uses education to improve their children's earnings and provide upward mobility. Aspirations have risen very rapidly. Rigidity of the system and its inability to fulfill raised aspirations are a cause of concern.

\section{Elements Of CONCERN}

The system of Indian higher education has evolved over the centuries, rooted in the country's history and culture. Since the first universities and colleges for modern higher education in the mid-Igth century, the focus has been on arts and humanities. As a result, half of the graduates have degrees in arts and humanities and almost four-fifths of graduates have no employable skills. Thus, India (like many other countries of the world) suffers a situation where critical levels of graduates' unemployment and skill shortages coexist. In contrast, for instance in the United States, despite a strong focus on liberal arts education, the growth of higher education over the centuries has had a strong vocational emphasis.

Another issue involves the rigidity of the archaic system that affiliates more than 18,000 colleges to 120 universities. The remaining 250 universities are nonaffiliating. The affiliating system was useful for rapid expansion of professional programs in engineering and medicine; the norms of professional practice were defined nationally. But in cases where academic autonomy is of paramount importance for defining curriculum and course content, an affiliating system becomes a bottleneck, stifling innovation and experimentation. Today's labor market requires a large diversity of skills in the graduates. The affiliating system has also resulted in small and nonviable colleges. Poorly resourced, such colleges are at best tutorial classes, where learning takes place on the basis of a fixed curriculum for the purpose of cracking exams.

The current accountability system of public institutions is extensive and cumbersome. With the purpose of higher education only ambiguously defined and with quality difficult to measure, public institutions often cover themselves with a fig leaf of autonomy wherever asked to deliver specific programs. The heavily unionized academic community, a powerful political constituency, is divorced from reality and resists change. Poorly financed and having teachers with low motivation levels, the standards of public institutions are deteriorating rapidly. Unfortunately, more public funding only addresses part of the problem.

$$
\begin{aligned}
& \text { Several sectors of the Indian economy face severe } \\
& \text { skill shortages perceived as caused by the inadequa- } \\
& \text { cy of the higher education system. }
\end{aligned}
$$

\section{Addressing Concerns}

Thus, the causes of Indian higher education's crisis stem from the system's structure rooted in its history and relate to the nature of higher education itself where purpose and quality are difficult to define. However, in response to societal pressure and market forces, Indian higher education has undergone a transformation over the past two decades in the explosive growth of private higher education. Even the public institutions have a large chunk of self-financing programs, most of them with a professional focus. This approach ensures a better matching of the graduates' skills with their own preferences 
and the demands of the labor market.

The growth of private institutions has created concerns about equity, quality, and exploitation. Since tuition fees are high for almost all professional education (whether at public or private institutions) - most people find only professional education useful-useful higher education is now inaccessible to the poor. Besides preventing the fees to rise in general higher education in the name of equity, very little is being done to introduce an adequately funded scholarship and loan scheme for the poor. Such an intervention is urgently required to promote access to higher education and address equity issues.

Accreditation agencies have been put in place to ensure quality and tightly regulated admissions and fees. Yet, progress has been limited due to a hiatus between what is said and what actually gets done. Due to lack of transparency and fair play (or perceptions of the same), private institutions lack the incentive to do the right things. Standards continue to fall and some private institutions indulge in gross malpractices, creating a poor overall image of private higher education.

Rather than dismantling the affiliating system (as some people suggest), the strengths of the system should be used to disperse higher education opportunities geographically through both a conventional and distance mode to address the quality issue. Consolidation of higher education requires the merging and clustering of universities and colleges, for intellectual exchange, synergy, and a sharing of infrastructure and facilities. And each such merged entity should be given full academic autonomy to experiment and innovate.

\section{CONCLUSION}

Overall, a four-pronged approach is required to meet the rising expectations and aspirations of the people. First, the private sector needs to be based on the current realities and applied in a fair and transparent manner. Second, the affiliating system needs to be designed to achieve geographical dispersal and to establish the optimum size of institutions. Third, increased funding and innovative financing mechanisms must create incentives for public institutions to do the right things and change with time. Fourth, an adequately funded scholarship and loan scheme should be put in place so that no one is denied the opportunity for higher education just because of poverty. Pragmatism requires understanding that the Indian government could at best set up more top-quality institutions and support public research, while sustained support for higher education and its growth would occur through private finance. Equity issues can be addressed through properly designed income-contingent loans and scholarships for the very poor. Private growth in the Indian context helps to correct the country's historical and undesirable bias for liberal arts education. Thus, at a time when the Indian economy is at takeoff stage, the government should direct and accelerate changes in Indian higher education to support the economy.

\section{Vedanta University: A Flawed Pipe Dream}

\section{Philip G. Altbach}

Philip G. Altbach is Monan professor of higher education and director of the Center for International Higher Education at Boston College.

$T_{1}$ he latest grandiose and probably unrealistic idea for establishing a world-class university is Anil Agarwal's Vedanta University, which is planned to be opened in 2008 in the state of Orissa, India. Mining magnate Agarwal has pledged an initial \$I billion for this project. International architects have been hired, the authorities in Orissa are on board, and a group of academic leaders is being hired from around the world. The idea is to create a university with 100,000 students, offering degrees in the major fields and stressing an interdisciplinary approach. While the details of the university's organization have not been revealed, it is intended to look like Harvard and Stanford. While it is always a good deed when one of the world's richest men takes an interest in higher education, it is unlikely that Vedanta University will achieve the desired results, no matter how much money Mr. Agarwal spends on it.

In India, where so much of the emerging private higher education sector is de facto for-profit and narrowly focuses on a few high-demand vocational fields, it is positive that a major industrialist is investing in higher education. The clear public interest motivation for Vedanta is also heartening as is the goal of planning a university that will offer an array of disciplines and not just business administration or information technology.

Does Vedanta have an overarching educational philosophy and strategy to obtain the goal of building a world-class university? Is there an educational vision behind the money? Building impressive physical facilities are a start but will by no means ensure success. The heart of any university consists of its faculty-the professors who do the actual academic work and who must have the autonomy to shape the institution's programs. Academic leadership is also a necessity-leadership with an intellectual vision as well as the ability to build and manage a complex organization.

A billion dollars sounds like a lot of money, but when spread around a university of 100,000 students, it is in fact a more modest sum. One must separate the cost of building the campus from the operating costs of a major research university. The annual budgets of universities like Harvard and Stanford are about \$I billion; the major European universities spend less but are in this league. An average American research university typically has an operating budget of close to a half billion.

No research university in the world has 100,000 students or even anything close. The University of Chicago, one of the few 